\title{
Association of IL2-330 Gene Polymorphism with Lung Cancer
}

\author{
IL2-330 Gen Polimorfizmin Akciğer Kanseri ile İlişkisinin Araştırılması
}

Oykum Genc'1, (D) Erdi Akar², (D) Erkan Arpaci³, (D) Huseyin Engin ${ }^{4}$, (D) Sevim Karakas Celik ${ }^{4}$

1-İstanbul Üniversitesi Fen Fakültesi, İstanbul, 2- Zonguldak Bülent Ecevit Üniversitesi Fen Bilimleri Enstitüsü, Zonguldak, 3- Sakarya Adatıp Hastanesi, Sakarya, 4- Zonguldak Bülent Ecevit Üniversitesi Tıp Fakültesi, Zonguldak.

\begin{abstract}
Cytokines are secreted or membrane-bound proteins that like mediators of intercellular signaling to regulate homeostasis of the immune system. They are produced by cells of innate and adaptive immunity in response to microbes and tumor antigens. Although several studies showing that IL2 -330 (rs2069762) gene polymorphism is associated with many types of cancer, as far as we know, a few studies investigating the association between lung cancer and IL2 -330 gene polymorphism. In this study, the role of IL2 -330 gene polymorphism in the pathogenesis of lung cancer was investigated. 96 patients who were diagnosed with lung cancer and 96 age and sex-matched healthy subjects participated in the study. Genomic DNA was isolated using the blood DNA isolation kit and the IL2 -330 gene polymorphism was determined by polymerase chain reaction-confronting two pairs primer method. When analyzed for the lung cancer group and the healthy group according to IL2 -330 gene polymorphism, genotype and allele frequencies were found to be similar in both groups $(p>0,05)$. As a result; there was no statistically significant difference between the groups. Considering the ethnic diversity of lung cancer, the study needs to be verified in other populations.

$\ddot{O} \boldsymbol{Z E T}$

Sitokinler, bağışıklık sisteminin homeostazını düzenlemek için hücreler arası sinyalleşmenin aracıları olarak görev yapan, salgılanan veya zara bağll proteinlerdir. Mikroplara ve tümör antijenlerine yanit olarak doğuştan gelen bağışıklığa sahip hücreler tarafindan üretilirler. IL2 -330 (rs2069762) gen polimorfizminin birçok kanser türü ile ilişkili olduğunu gösteren birkaç çalışma olmasına rağmen, bildiğimiz kadarıyla akciğer kanseri ile IL2 -330 gen polimorfizmi arasındaki ilişkiyi araştıran az sayıda çalışma vardır. Bu çalışmada IL2 -330 gen polimorfizminin akciğer kanseri patogenezindeki rolü araștırılmıştır. Çalıșmaya akciğer kanseri tanısı almış 96 hasta ile yaş ve cinsiyet bakımından uyumlu 96 sağlıklı, gönüllü birey katıldı. Genomik DNA izolasyon kiti kullanılarak izole edildi ve IL2 -330 gen polimorfizmi polimeraz zincir reaksiyonu ile iki çift primer yöntemiyle karșılaștırılarak belirlendi. Akciğer kanserinde IL2 -330 gen polimorfizmine göre hasta grubu ve sağllklı grup incelendiğinde genotip ve allel frekanslarının her iki grupta benzer olduğu görüldü ( $p>0,05)$. Sonuç olarak gruplar arasında istatistiksel olarak anlamlı bir fark yoktu. Akciğer kanserinin etnik çeşitliliği göz önüne alındığında, çalışmanın diğer popülasyonlarda da doğrulanması gerekmektedir.
\end{abstract}

Keywords:

Cytokines

Interleukine 2

IL2

Lung Cancer

Polymorphism

\section{INTRODUCTION}

According to the World Health Organization (WHO) report, lung cancer is the most common cancer type in males worldwide, and the second most common cancer type in females also causes about 1.3 million deaths worldwide each year. The most common cause of lung cancer is long-term exposure to tobacco smoke, and nearly $15 \%$ of all lung cancer patients are non-smokers. Therefore, it is known that genetic factors play important role in the pathogenesis of lung cancer (1).

The immune system cells secrete a large number of reporter proteins, which regulate the division of the host cell and are involved in innate and acquired immune responses. These reporters are called cytokines (2). IL2, a potent immune regulatory cytokine involved in cellmediated immune response, is produced by $\mathrm{T}$ cells when it is activated by mitogens, or by the interaction of antigen with major histocompatibility complexes and also like as a T-cell growth factor (3).

The immune system is organized such that it does not respond to our antigens (4). However, as cancer cells acquire many mutations and changes (5), they express tumor-specific antigens with sporadic mutations, thereby activating the immune system, eventually leading to the killing of cancer cells. Thus, the immune system can prevent the formation of primary tumors (6).

However, mutational changes occurred as cancer cells continued to divide, accumulating either by chance or in response to immune-induced inflammation. Also, due to genetic instability, fixed tumor cell division can produce low immunogenicity that can escape immune elimination (7).

The human IL2 gene is localized on chromosome $4 \mathrm{q} 26$. In the human IL2 gene, two major polymorphisms have

Correspondence: Öyküm GENÇ, Istanbul University, Faculty of Sciences, Department of Biology Vezneciler/Fatih/Istanbul/ TURKEY. E-mail: gencoykum@gmail.com

Cite as: Genc O, Akar E, Arpaci E, Engin H, Celik SK. Association of IL2 -330 Gene Polymorphism with Lung Cancer. Phnx Med J. 2021;3(2):81-84.

Received: 01.03.2021

Accepted: 08.06 .2021 


\section{Genc et al.}

been identified: one is located in the promoter region at nucleotide -330 (8) and the other in the first exon at position +114 (9). G -330T (rs2069762), identified upstream of the IL2 promoter-enhancer domain, reportedly affects protein production. Individuals that were homozygous for the $\mathrm{G}$ allele $(\mathrm{G} / \mathrm{G})$ in the promoter region of the IL-2 gene produced more than three times more IL-2 than individuals that $\mathrm{G} / \mathrm{T}$ and $\mathrm{T} / \mathrm{T}$ genotypes (10).

We hypothesized that this SNP may be associated with lung cancer risk, as IL2 plays important role in the regulation of immune response and the process of inflammation-mediated carcinogenesis, and also because of its functional association with IL2-330 T/G. To test this hypothesis, we performed genotyping analyzes for this SNP in a case-control study of lung cancer patients and healthy controls in a Turkish population.

\section{METHOD}

\section{Study Population}

The case-control group consisted of 96 patients diagnosed with lung cancer in Zonguldak Bülent Ecevit University Medical Oncology Department and 96 healthy individuals. The patient group was diagnosed with chest X-ray, sputum cytology, and computed tomography imaging tests. This study was approved by the Zonguldak Bulent Ecevit University Clinical Research Ethics Committee (201705-11/01) in 2017, and written informed consent was obtained from each participant.

\section{DNA Isolation and Genotyping}

Genomic DNA was extracted from 200 microliter of peripheral blood using the E.Z.N.A Blood DNA isolation
Kit (Omega Bio-Tek, Norcross, GA, USA) following the manufacturer's instructions. The polymorphism in the -330 region of the IL2 gene was analyzed by the Confronting two pairs primer method (8). The PCR mix contains 20 pmol from each of the primers (Table 1), 125 mM dNTP, $125 \mathrm{mM}$ Taq DNA buffer, $125 \mathrm{mM} \mathrm{MgCl2,}$ $15 \mathrm{mM}$ Taq DNA Polymerase in a final volume of $25 \mu \mathrm{l}$. PCR reaction conditions; 1 cycle $95^{\circ} \mathrm{C}$ for 5 minutes, then 35 cycles of $95^{\circ} \mathrm{C}$ for 1 minute and $57{ }^{\circ} \mathrm{C}$ for 1 minute, $72{ }^{\circ} \mathrm{C}$ for 1 minute followed 1 cycle $72{ }^{\circ} \mathrm{C}$ for 7 minutes. PCR products were visualized on $3 \%$ agarose gel electrophoresis. For the $\mathrm{G}$ allele, a band of $152 \mathrm{bp}$ was obtained and for the T allele, a band of 215 bp was obtained. A 312 bp band is common in all samples (Figure $1)$.

Tablo 1: Confronting two pairs primer sequence

\begin{tabular}{ll}
\hline Primers & Sequence \\
\hline F1 & 5'-CTG ACA TGT AAG AAG CAA \\
& TCT AT-3' \\
R1 & 5'-CTC AGA AAA TTT TCT TTG \\
& TCC-3' \\
F2 & 5'-TTC ACA TGT TCA GTG TAG \\
& TTT TAT-3' \\
R2 & 5'- TGT TAC ATT AGC CCA CAC \\
& TTA-3' \\
\hline
\end{tabular}

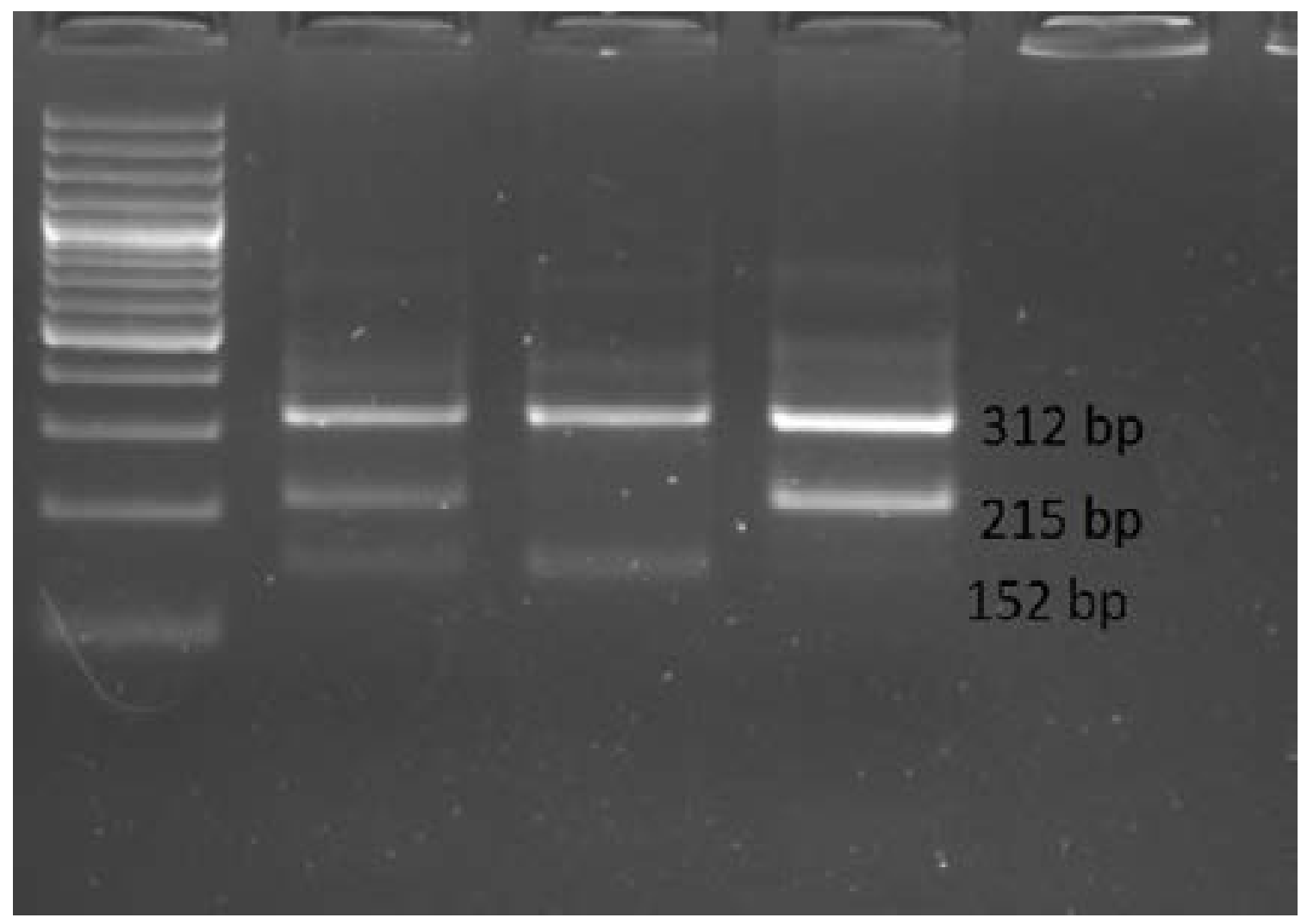

Figure 1: Genotyping by electrophoresis: (right to left) GG, TT, and GT genotype. The first well is a $100 \mathrm{bp}$ DNA ladder. Base pairs are indicated in the figure. 


\section{Phnx Med J. July 2021, Volume 3 No 2}

\section{Statistical Analysis}

A case-control study was performed and the allelic frequency of the polymorphism was calculated in both cases and controls. Deviations from Hardy-Weinberg equilibrium were evaluated by comparing observed and expected genotype frequencies. The $x^{2}$ test was used to compare the genotype frequency of IL2 gene polymorphism in lung cancer patients and controls. The odds ratio (OR) and 95\% confidence interval (CI) were calculated to compare the lung cancer risk for the alleles. $\mathrm{p}$ values $<0.05$ were considered to indicate statistical significance. The SPSS software was used (ver. 18.0; SPSS Inc., Chicago, IL).

\section{RESULTS}

The mean age of the lung cancer patient group was $43.26 \pm 10.54$, the mean age of the control group was $45.8 \pm 10.62$. The patient and control groups were compared in terms of gender. There was no statistically significant difference was found between the groups $(\mathrm{p}>0.05)$ (Table 2).

Table 2: Demographic features of patients and control group

\begin{tabular}{lccc}
\hline & Control & Patient & p-value \\
\hline $\begin{array}{l}\text { Age (years, } \\
\text { Mean } \pm \text { SD) }\end{array}$ & $45.8 \pm 10.62$ & $43.26 \pm 10.54$ & 0.097 \\
\hline Sex & & & \\
\hline Male & $89(50.3 \%)$ & $88(49.7 \%)$ & 1.0 \\
Female & $7(46.7 \%)$ & $8(53.3 \%)$ & \\
\hline
\end{tabular}

In this study, the association between lung cancer and IL2 -330 (rs2069762) polymorphism was investigated and it was found that the frequencies of TT, GT, and GG genotypes were $21.9 \%, 67.7 \%$, and $10.4 \%$ in the patient group and were $17.7 \%, 79.2 \%$ and $3.1 \%$ in the control group, respectively. There was no statistically significant difference between these two groups (Table 3).

For IL2 -330 T / G polymorphism, T allele frequencies were $55.7 \%$ in lung cancer patients and $56.5 \%$ in the control group. $\mathrm{G}$ allele frequency was determined as $44.3 \%$ in lung cancer patients and $43.5 \%$ in the controls (Table 4). There was no statistically significant difference between the groups.

\section{DISCUSSION}

Cytokines are small glycoproteins that bind to cell surface receptors and regulate the development, survival, and function of immune cells (11). IL2 is one of the key cytokines with pleiotropic effects on the immune system. This immunoregulatory cytokine IL2 plays an important role in the antitumor immunoreactivity of T cells, and the polymorphism in the -330 promoter region is the most investigated (12). However, in the present case-control study, our results indicated that there was no association between IL2 -330 rs2069762 gene polymorphism and lung cancer. Few reports regarding the association between the IL2 gene polymorphism and lung cancer have been published. A case-control study by Eaton KD et al., it was investigated the role of genetic polymorphisms in inflammation-related genes in the risk for development of lung cancer in 625 cases and 625 matched controls.

Table 3: Association between lung cancer and IL2 -330 T/G polymorphism according to genotype frequency

\begin{tabular}{lccccc}
\hline IL2 -330 & Case n (\%) & Control n (\%) & Total n (\%) & p & OR (95\% CI) \\
\hline TT & $21(21.9 \%)$ & $17(17.7 \%)$ & $38(19.8 \%)$ & 0.100 & Reference \\
GT & $65(67.7 \%)$ & $76(79.2 \%)$ & $141(73.4 \%)$ & 0.317 & $0.692(0.337-1.423)$ \\
GG & $10(10.4 \%)$ & $3(3.1 \%)$ & $13(6.8 \%)$ & 0.177 & $2.698(0.639-11.389)$ \\
\hline
\end{tabular}

Table 4: Association between lung cancer and IL2 -330 T/G rs2069762 polymorphism of the allele frequency

\begin{tabular}{lccccc}
\hline IL2 -330 & Case n (\%) & Control n (\%) & Total n (\%) & p & OR 95\% CI \\
\hline T & $107(55.7 \%)$ & $110(57.3 \%)$ & $217(56.5 \%)$ & 0.757 & Reference \\
G & $185(44.3 \%)$ & $82(42.7 \%)$ & $167(43.5 \%)$ & 0.837 & $1.066(0.712-1.59)$ \\
Total & $292(100 \%)$ & $192(100 \%)$ & $384(100 \%)$ & 0.837 & \\
\hline
\end{tabular}

Similarly, with our results, the study did not find any correlation between genotype and lung cancer risk for the IL2 rs2069762 and rs2069763 polymorphisms (13).

In several studies, genetic polymorphisms of the IL2 -330 $\mathrm{T} / \mathrm{G}$ have been implicated in the susceptibility to a range of inflammatory diseases and cancer, including gastric atrophy from Helicobacter pylori infection, myelogenous leukemia $(14,15,16,17)$, gastric cancer (18), lung cancer (19), and breast cancer (20). However, other studies have shown that IL2 -330T / G polymorphism is not associated with gastric cancer or cutaneous malignant melanoma. The first meta-analysis which provided comprehensive information of the association on IL2 -330 $\mathrm{T} / \mathrm{G}$ polymorphism and cancer risk was performed by
Hongyu Zhao et al. and this study showed that IL2 -330 $\mathrm{T} / \mathrm{G}$ polymorphism is strongly associated with lymphoma risk, whereas the association between gastric cancer and IL2 -330 T/G polymorphism is not significant (21).

Song N. et al. investigated the genetic susceptibility of childhood lymphoma and reported that sixteen SNPs in six genes (IL1RN, IL2, IL12RB1, JAK3, TNFRSF13B, and $\mathrm{XRCC} 3$ ) were significantly associated with the risk of lymphoma $(\mathrm{p}<0.05)$. The most important association was found in the IL2 (- $330 \mathrm{~T} / \mathrm{G})$ polymorphism (22). Also, Torres-Mejía G. et al. (2012) showed that IL2 and IL2RA were associated with the risk of breast cancer (4).

In addition, Wei YS et. al. investigated whether the IL2 gene polymorphism and serum levels were related to 


\section{Genc et al.}

nasopharyngeal carcinoma in the Chinese population. It was reported that there was a significant difference in the IL2 -330 T/G polymorphism genotype distributions between patients with nasopharyngeal carcinoma and the control group $(\mathrm{p}<0.005)$. Moreover, there was a decrease in serum IL2 levels when compared with the wild-type allele in patients with nasopharyngeal carcinoma carrying the IL2 -330 G variant allele (23).

There are some limitations to this study. First, we did not adjust other compounding variables for risk factors of lung cancer, such as tobacco smoke, environmental factors, and family history. Second, the number of samples was relatively small for the investigation of genetic polymorphisms. Further studies with large samples and including environmental, other host genetic factors will be needed.

\section{CONCLUSION}

Our study is the first study investigating the association between lung cancer and IL2 rs2069762 polymorphism. Because lung cancer shows ethnic variation, repeating the study with more samples in different populations will contribute to the understanding of the relationship.

Ethics: This study was also approved by the Zonguldak Bulent Ecevit University Clinical Research Ethics Committee (2017-05-11/01) in 2017 and written informed consent was obtained from each participant.

Conflict of Interest: No conflict of interest was declared by the authors.

Oral Presentation: IV. International Congress on Applied Biological Sciences, Eskişehir, Türkiye, 3 - 5 Mayıs 2018

\section{REFERENCES}

1. Medler Terry R, Cotechini Tiziana, Coussens Lisa M. Immune response to cancer therapy: mounting an effective antitumor response and mechanisms of resistance. Trends in cancer. 2015;1:66-75.

2. Bindon C, Czerniecki M, Ruell P, Edwards A, McCarthy WH, Harris R, Hersey P. Clearance rates and systemic effects of intravenously administered interleukin 2 (IL-2) containing preparations in human subjects. British journal of cancer. 198347(1);123-133.

3. Seder RA, Paul WE. Acquisition of lymphokine-producing phenotype by CD4+ T cells. Annual review of immunology, 1994 ; 2 (1):635-673.

4. Torres-Mejía G, Angeles-Llerenas A, Ortega-Olvera C, Lazcano-Ponce E, Ziv E, Pulido-Rodríguez J, et al. Moderate-intensity physical activity ameliorates the breast cancer risk in diabetic women. Diabetes Care,.2012;35(12):2500-2502.

5. Malek TR, Bayer AL. Tolerance, not immunity, crucially depends on IL-2. Nature Reviews Immunology. 2004:4(9):665-674

6. Mellman I, Coukos G, Dranoff G. Cancer immunotherapy comes of age. Nature, 2011;480;480-489.

7. Winchester DA, Till C, Goodman PJ, Tangen CM, Santella RM, Johnson-Pais TL, et al. Variation in genes involved in the immune response and prostate cancer risk in the placebo arm of the Prostate Cancer Prevention Trial. The Prostate. 2015;75(13),:1403-1418.

8. John S, Turner D, Donn R, Sinnott P, Worthington J, Ollier WER, et al. Two novel biallelic polymorphisms in the IL-2 gene. European Journal of Immunogenetics. 1998;25(6);419-420.

9. Matesanz F, Delgado C, Fresno M, Alcina A. Allelic selection of human IL-2 gene. European journal of immunology. 2010;30(12):3516-3521.

10. Hoffmann SC, Stanley EM, Cox ED, Craighead N, DiMercurio BS, Koziol DE, et al. Association of cytokine polymorphic inheritance and in vitro cytokine production in anti-cd3/cd28-stimulated peripheral blood lymphocytes1. Transplantation. 2001;72(8):1444-1450.

11. Noronha IL, Niemir Z, Stein H, Waldherr R. Cytokines and growth factors in renal disease. Nephrology Dialysis Transplantation. 1995;10(6):775786.

12. Smith AJ, Humphries SE. Cytokine and cytokine receptor gene polymorphisms and their functionality. Cytokine \& growth factor reviews. 2009;20(1):43-59.

13. Melchiades JL, Zabaglia LM, Sallas ML, et al. Polymorphisms and haplotypes of the interleukin 2 gene are associated with an increased risk of gastric cancer. The possible involvement of Helicobacter pylori. Cytokine. 2017;96:203-207.

14. Amirzargar AA, Bagheri M, Ghavamzadeh A, Alimoghadam K, Khosravi F, Rezaei N, Nikbin B, et al. Cytokine gene polymorphism in Iranian patients with chronic myelogenous leukaemia. International journal of immunogenetics. 2005;32(3):167-171.

15. Togawa S, Joh T, Itoh M, Katsuda N, Ito H, Matsuo K, et al. Interleukin-2 gene polymorphisms associated with increased risk of gastric atrophy from Helicobacter pylori infection. Helicobacter. 2005;10(3):172-178.

16. Shin WG, Jang JS, Kim HS, Kim SJ, Kim KH, Jang MK, et al. Polymorphisms of interleukin-1 and interleukin-2 genes in patients with gastric cancer in Korea. J Gastroenterol Hepatol. 2008;23(10):1567-1573.

17. Wu J, Lu Y, Ding YB, Ke Q, Hu ZB, Yan ZG, et al. Promoter polymorphisms of IL2, IL4, and risk of gastric cancer in a high-risk Chinese population. Mol Carcinog. 2009;48(7):626-632.

18. Forones NM, Mandowsky SV, Lourenço LG. Serum levels of interleukin-2 and tumor necrosis factor-alpha correlate to tumor progression in gastric cancer. Hepatogastroenterology. 2001;48(40):1199-1201.

19. Orditura M, Romano C, De Vita F, Galizia G, Lieto E, Infusino S, et al. Behaviour of interleukin-2 serum levels in advanced non-small-cell lung cancer patients: relationship with response to therapy and survival. Cancer Immunol Immunother. 2000;49(10):530-536.

20. Klein B, Levin I, Kfir B, Mishaeli M, Shapira J, Klein T. The significance of soluble interleukin-2, soluble interleukin-2 receptors, soluble ICAM-1 and beta 2-microglobulin in breast cancer patients. Tumour Biol. 1995;16(5):290-296.

21. Zhao H, Wang R. IL2 -330T/G polymorphism and cancer risk: a meta-analysis. Onco Targets Ther. 2015;8:1753-1760.

22. Song N, Han S, Lee KM, Choi JY, Park SK, Jeon S, et al. Genetic variants in interleukin-2 and risk of lymphoma among children in Korea. Asian Pac J Cancer Prev. 2012;13(2):621-623.

23. Wei YS, Lan Y, Zhang L, Wang JC. Association of the interleukin-2 polymorphisms with interleukin-2 serum levels and risk of nasopharyngeal carcinoma. DNA Cell Biol. 2010;29(7):363-368. 